\title{
Editorial
}

\section{Innovation Management and Entrepreneurship-Introduction}

\author{
Luísa Cagica Carvalho ${ }^{1, * \mathbb{C}}$ and Maria José Madeira ${ }^{2}$ (D) \\ 1 Institute Polytechnic of Setúbal and CEFAGE, Campus do IPS, ESCE, University of Évora, \\ 2810-583 Setúbal, Portugal \\ 2 NECE Research Center in Business Sciences, University of Beira Interior, 6201-001 Covilhã, Portugal; \\ maria.jose.madeira@ubi.pt \\ * Correspondence: luisa.cagica.carvalho@gmail.com
}

check for

updates

Citation: Carvalho, Luísa Cagica, and Maria José Madeira. 2021. Innovation Management and Entrepreneurship-Introduction. Administrative Sciences 11: 73. https: / /doi.org/10.3390/admsci 11030073

Received: 13 July 2021

Accepted: 14 July 2021

Published: 20 July 2021

Publisher's Note: MDPI stays neutral with regard to jurisdictional claims in published maps and institutional affiliations.

Copyright: (c) 2021 by the authors. Licensee MDPI, Basel, Switzerland. This article is an open access article distributed under the terms and conditions of the Creative Commons Attribution (CC BY) license (https:// creativecommons.org/licenses/by/ $4.0 /)$.
Entrepreneurship and innovation are positively related (Zhao 2005; Kyvik 2018; Sant et al. 2020). They are part of the same coin, like heads and tails. Entrepreneurship and innovation are considered the drivers of competitiveness and economic growth (Singh and Gaur 2018; Valliere and Peterson 2009), enhancing job creation and a country's social and economic development (Thornton et al. 2011). According to Audretsch and Thurik (2000) and Audretsch et al. (2001), start-ups enable economic growth and are the indispensable vehicle for achieving high levels of competitiveness and innovation (Wennekers and Thurik 1999). Moreover, these firms revitalize traditional sectors and create new businesses that boost the economy. According to Hay et al. (2002), new businesses prove to be an important factor in the economic development of a region and a country.

Entrepreneurship is revealed in the emergence of new business initiatives such as creating a new company or a new business (including self-employment) and developing new projects in existing companies (Reynolds et al. 1999, p. 3). It is a process that can be developed by a single individual or by more people, independently or integrated into an existing organization. In the current context, under the pressure of Covid, "entrepreneurship, defined as the process of starting and running a new business, is of primary importance" (Bosma et al. 2021, p. 13).

To better understand entrepreneurship, it is essential to look for its origins. The term entrepreneurship is derived from the French "entre" and "prendre", meaning to be in the market between the supplier and the consumer (Sarkar 2014). The term originated from the French, "entrepreneur," meaning one who takes risks and starts something new. The term was first used in the 18th century by Richard Cantillon, an economist who, in 1755, defined and differentiated entrepreneurship from capitalism. For Cantillon (1755), an entrepreneur is the individual who buys raw materials, processes them, and sells them to another individual for an uncertain price because he identifies a business opportunity and takes a risk.

In 1776, the term "entrepreneurship" was used by Adam Smith in his book "Wealth of Nations," where he defined entrepreneurs as individuals who react to changes in the economy, acting as an economic agent, and who transform a demand into supply (Smith 1776). Say (1803) said that the concept of the entrepreneur is associated with the individual who buys, transforms, and sells raw materials, identifying a business opportunity and, to do so, takes risks.

Schumpeter (1934) presents how economic development is driven by innovation through dynamic processes of "creative destruction" in which new technologies replace existing ones. Under this view, Schumpeter proposed the following forms of innovation: (1) introduction of new goods; (2) introduction of new forms of production; (3) discovery of a new source of raw materials or semi-elaborated products; (4) opening of a new market; and (5) creating new market structures in the industry. Schumpeter (1934) defined innovation as "new combinations of existing resources" and called this combinatory activity the 
"innovative function" associated with entrepreneurial activity. Thus, Schumpeter was considered the first author to link the term entrepreneurship with innovation.

Drucker (1986) states that innovation is the specific tool of entrepreneurs, through which they exploit change as an opportunity for a different business or service. According to the author, entrepreneurs should look for sources of innovation, new trends, and new signals, which indicate opportunities to develop successful innovations.

According to Sarkar (2014), innovation is the conjunction of several elements. It is necessary to have an idea, realize the opportunities, choose the best alternative, apply the idea and make it successful in the market, avoiding that it remains in the condition of the invention. Strobel and Kratzer (2017) defined innovation as introducing new products and processes and implementing new ideas that create value. Innovation can be an idea, practice, or material artefact, perceived as new by the relevant adoption unit.

The fourth edition of the Oslo Manual (OECD 2018) states that there are two types of innovation: product innovation and process innovation. Product innovation refers to introducing a new or improved good or service that differs significantly from previous goods or services produced by the firm. Process innovation is a new or significantly improved process that differs from previously used and implemented processes in the firm to achieve greater competitiveness, effectiveness, and efficiency in the use of resources (OECD 2018).

Given the importance of innovation and entrepreneurship in the economy, particularly in society, developing a special issue stimulates further knowledge about entrepreneurship and innovation.

The research on innovation management and entrepreneurship proposes distinctive perspectives. It will be possible to find an explicit focus on innovative entrepreneurial activity, especially on high-growth innovative firms. But also, we can see some research that emphasizes the influence of public policies and local and regional environments and the conditions required to generate and support ambitious entrepreneurship and interactions between framework conditions and local/regional geographical environments.

These several perspectives allow the inclusion of different topics, such as 'regional development and smart cities, ' innovation,' 'cluster' policies,' 'technology transfer,' 'business incubators,' 'entrepreneurial universities, ' triple helix,' 'academic spin-offs,' 'creative territories,' 'digital ecosystems, ' 'public policies and innovation,' 'innovative firms,' 'KIBS,' 'high tech firms', etc.

Several researchers worldwide have been studying the subjects of entrepreneurship and innovation, and contributions are multidisciplinary and diverse and their topics of interest. And emerging new trends aligned with the challenges faced by organizations and societies. Technology and digitalization come as new entrepreneurship opportunities and bring new solutions and possibilities for innovation (3D print, IoT, Artificial Intelligence; Blockchain, etc.).

New Business Models links digitalization and with the circular economy (Lewandowski 2016). Some of them mix digitalization and circularity and appear as strategies to minimize the environmental impacts of economic activity. They also promote changes in the market, with some products coming to the market as services (Kohtamäki et al. 2019).

Another trend influenced by business models is the sharing economy. Collaborative consumption can change the world, allowing those million people worldwide access to products and services without ownership. Social media and smart technological networks allow innovative systems based on shared consumption and collaborative business models (Cohen and Kietzmann 2014).

Additionally, cocreation comes as an opportunity for entrepreneurship. The strategy of cocreation implies the creation of value in a shared and collaborative way by several stakeholders that obtain mutual benefits. This strategy involves suppliers, producers, clients, academia, etc., to create or produce solutions and even products or services. Prahalad and Ramaswamy (2004) propose this nomenclature; however other concepts are linked, such as open innovation (Chesbrough 2006) or crowdsourcing (Howe 2009). All 
of them imply the creative participation of persons and entities to share resources, find solutions or create value for new or existing businesses.

In summary, new avenues are open to continuing the research in the fields of entrepreneurship and innovation. This special issue offers an opportunity to continue the discussion and present new contributions.

The Special Issue of Innovation management and entrepreneurship aims to create a space for reflection and discussion on entrepreneurship and innovation management topics attending several perspectives on literature, systematic review, empirical studies, case studies, and mixed-methods investigation.

The special issue starts with a paper entitled "Generation $\mathrm{Z}$ and Key-Factors on ECommerce: A Study on the Portuguese Tourism Sector." This paper discussed the role of tourism in Portugal. The study's findings have been discussed in the light of relevant literature in the field key factors in the decision to purchase tourism products/services in Generation $\mathrm{Z}$ and have practical and theoretical implications. This study allows us to establish the bases for future research, to help researchers understand Generation $Z$ consumption habits (Vieira et al. 2020).

The second paper is entitled "Linking Structural Empowerment to Employee-Driven Innovation: The Mediating Role of Psychological Empowerment." This paper has dealt with how important structural empowerment to employee-driven innovation (EDI) with psychological empowerment as a mediation mechanism. Comes to respond to increasing interest in utilizing all sources of knowledge in an organization to stimulate innovation among all employees. A clear understanding of some of the mechanisms used to achieve this is needed (Echebiri et al. 2020).

The third paper in this special issue is titled "Survival and Growth in Innovative Technology Entrepreneurship: A Mixed-Methods Investigation." For a firm to grow and succeed, it has to identify the characteristics that entrepreneurs and employees should bear towards its survival and growth, especially in the Innovative Technology Entrepreneurship that is recognized internationally as an important pillar in modern economic activity. This research combined qualitative and quantitative methods. Also, the results can help guide future theoretical and practical endeavors in innovative technology entrepreneurship (Eliakis et al. 2020).

The fourth paper is entitled "Results of SME Investment Activities: A Comparative Analysis among Enterprises Using and Not Using EU Subsidies in Poland." This paper has tried to fill in the gap and supplements the knowledge on the economic effects of investments implemented by enterprises in the SME sector in Poland in a situation where these entities used and did not benefit from EU subsidies. The findings of this study show that undertaking investment activities contribute to obtaining favorable results in enterprises, regardless of the source of investment financing. Entities that have received EU subsidies have a stronger perception of investment as an important factor determining the company's development (Piatkowski 2020).

This special issue moves on to the fifth paper entitled "Models, Processes, and Roles of Universities in Technology Transfer Management: A Systematic Review." This paper details some existing models, processes, and roles that are taken up in some countries where sharing of intellectual property exists and links it up with aspects of university-industry technology transfer, such as policies surrounding patenting, government investment and marketing, and the process of academic entrepreneurship, among others. The findings of the systematic review of literature focus on four identified areas: internal strategy, investment and market, academic entrepreneurship and policy. The findings of this study have significant managerial implications and theoretical contributions (Maresova et al. 2019).

The last paper is entitled "Performance Analysis and Science Mapping of Institutional Entrepreneurship Research." Institutional entrepreneurship is somewhat complex, fragmented, and disparate due to many scholarly publications. This paper has tried to compile a quantitative overview of business and management research by conducting bibliometric 
performance analyses and science mappings. The findings of this paper provide practical and theoretical implications for institutional entrepreneurship (Tiberius et al. 2020).

We hope that the special issue on "Innovation management and entrepreneurship" with six articles can provide varied perspectives and insights into innovative entrepreneurial activity, and contributions are multidisciplinary and diverse. The readers will like this special issue for its challenging papers research-based: a quantitative approach, a MixedMethods Investigation, a Systematic Review, and management research by conducting bibliometric performance analyses and science mappings.

Funding: The first author acknowledge to Fundação para a Ciência e Tecnologia (Grant number: UIDB $/ 04007 / 2020$ ). The second author acknowledge to NECE-UBI, this paper is financed by National Funds provided by FCT-Foundation for Science and Technology through project UIDB/04630/2020.

Conflicts of Interest: The authors declare no conflict of interest.

\section{References}

Audretsch, David B., and A. Roy Thurik. 2000. Capitalism and democracy in the 21st century: From the managed to the entrepreneurial economy. Journal of Evolutionary Economics 10: 17-34. [CrossRef]

Audretsch, David B., Martin A. Carree, and Adriaan Roy Thurik. 2001. Does Entrepreneurship Reduce Unemployment? (No. 01-074/3). Tinbergen Institute Discussion Paper. Jena: Max-Planck-Institute of Economics, Available online: https://www.econstor.eu/ bitstream/10419/25654/1/553694472.PDF (accessed on 19 July 2021).

Bosma, Niels, Stephen Hill, Aileen Ionescu-Somers, Donna Kelley, Maribel Guerrero, Thomas Schott, and the Global Entrepreneurship Research Association. 2021. GEM Global Report 2020/2021. London: Global Entrepreneurship Research Association, London Business School, Regents Park.

Cantillon, Richard. 1755. An Essay on Commerce in General. History of Economic Thought Books. Hamilton: McMaster University.

Cohen, Boyd, and Jan Kietzmann. 2014. Ride On! Mobility Business Models for the Sharing Economy. Organization E Environment 27: 279-96. [CrossRef]

Chesbrough, Henry. 2006. Open Business Models: How to Thrive in the New Innovation Landscape. Harvard: Harvard Business Press. EUA.

Drucker, Peter. 1986. Inovação e Gestão. Lisboa: Editorial Presença.

Echebiri, Chukwuemeka, Stein Amundsen, and Marit Engen. 2020. Linking Structural Empowerment to Employee-Driven Innovation: The Mediating Role of Psychological Empowerment. Administrative Sciences 10: 42. [CrossRef]

Eliakis, Stelios, Dimosthenis Kotsopoulos, Angeliki Karagiannaki, and Katerina Pramatari. 2020. Survival and Growth in Innovative Technology Entrepreneurship: A Mixed-Methods Investigation. Administrative Sciences 10: 39. [CrossRef]

Hay, Michael, Larry W. Cox, Paul D. Reynolds, Erkko Autio, William D. Bygrave, and the Ewing Marion Kauffman Foundation. 2002. Global Entrepreneurship Monitor Gem-2002 Executive Report. Available online: https://www.researchgate.net/publication/273705 516_Global_Entrepreneurship_Monitor_2002_Executive_Report (accessed on 19 July 2021).

Howe, Jeff. 2009. Crowdsourcing: Why the Power of the Crowd Is Driving the Future of Business. New York: Penguin.

Kohtamäki, Marko, Vinit Parida, Pejvak Oghazi, Heiko Gebauer, and Tim Baines. 2019. Digital servitization business models in ecosystems: A theory of the firm. Journal of Business Research 104. [CrossRef]

Kyvik, Oyvin. 2018. The global mindset: A must for international innovation and entrepreneurship. International Entrepreneurship and Management Journal 14: 309-27. [CrossRef]

Lewandowski, Mateusz. 2016. Designing the business models for circular economy towards the conceptual framework. Sustainability 8: 43. [CrossRef]

Maresova, Petra, Ruzena Stemberkova, and Oluwaseun Fadeyi. 2019. Models, Processes, and Roles of Universities in Technology Transfer Management: A Systematic Review. Administrative Sciences 9: 67. [CrossRef]

OECD. 2018. Oslo Manual 2018: Guidelines for Collecting, Reporting and Using Data on Innovation, 4th ed. Paris/Eurostat, Luxembourg: OECD Publishing. [CrossRef]

Piątkowski, Marcin J. 2020. Results of SME Investment Activities: A Comparative Analysis among Enterprises Using and Not Using EU Subsidies in Poland. Administrative Sciences 10: 4. [CrossRef]

Prahalad, Coimbatore K., and Venkat Ramaswamy. 2004. Cocreation experiences: The next practice in value creation. Journal of Interactive Marketing 18: 5-14. [CrossRef]

Reynolds, Paul D., Michael Hay, and S. Michael Camp. 1999. Global Entrepreneurship Monitor. Kansas City: Kauffman Center for Entrepreneurial Leadership.

Sant, Tomás Dias, Paulo Henrique de Souza Bermejo, Marina Fiqueiredo Moreira, and Wagner Vilas Boas de Souza. 2020. The structure of an innovation ecosystem: Foundations for future research. Management Decision 58: 2725-42.

Sarkar, Soumodip. 2014. Empreendedorismo e Inovação, 3rd ed. Lisboa: Escolar Editora.

Say, Jean-Baptiste. 1803. Traité D'économie Politique ou Simple Exposition. Deterville. vol. 2. Available online: https://gallica.bnf.fr/ark: /12148/btv1b86265547/f9.image (accessed on 19 July 2021).

Schumpeter, Joseph. 1934. The Theory of Economic Development. London: Oxford Press. 
Singh, Sanjay Kumar, and Sanjaya S. Gaur. 2018. Entrepreneurship and innovation management in emerging economies. Management Decision 56: 2-5. [CrossRef]

Smith, Adam. 1776. The Wealth of Nations. Available online: https://gulbenkian.pt/publication/riqueza-das-nacoes-i/ (accessed on 19 July 2021).

Strobel, Natalia, and Jan Kratzer. 2017. Obstacles to innovation for SMEs: Evidence from Germany. International Journal of Innovation Management 21: 1750030. [CrossRef]

Thornton, Patricia H., Domingo Ribeiro-Soriano, and David Urbano. 2011. Socio-cultural factors and entrepreneurial activity: An overview. International Small Business Journal 29: 105-18. [CrossRef]

Tiberius, Victor, Meike Rietz, and Ricarda B. Bouncken. 2020. Performance Analysis and Science Mapping of Institutional Entrepreneurship Research. Administrative Sciences 10: 69. [CrossRef]

Valliere, Dave, and Rein Peterson. 2009. Entrepreneurship and economic growth: Evidence from emerging and developed countries. Entrepreneurship \& Regional Development 21: 459-80.

Vieira, Jorge, Rui Frade, Raquel Ascenso, Inês Prates, and Filipa Martinho. 2020. Generation Z and Key-Factors on E-Commerce: A Study on the Portuguese Tourism Sector. Administrative Sciences 10: 103. [CrossRef]

Wennekers, Sander, and Roy Thurik. 1999. Linking entrepreneurship and economic growth. Small Business Economics 13: 27-56. [CrossRef]

Zhao, Fang. 2005. Exploring the synergy between entrepreneurship and innovation. International Journal of Entrepreneurial Behavior $\mathcal{E}$ Research 11: 25-41. 